\title{
PRODUKSI DAN PEMANFAATAN ARANG DAN CUKA KAYU DARI SERBUK GERGAJI KAYU CAMPURAN
}

\section{(Production and Utilization of Charcoal and Wood Vinegar of Mixture Wood Sawdust)}

\author{
Oleh/By : \\ Tjutju Nurhayati ${ }^{1)}$, Ridwan Ahmad Pasaribu' ${ }^{1)}$ \& Dida Mulyadi ${ }^{2)}$
}

\begin{abstract}
Integrated production study of charcoal and wood vinegar using mixed wood sawdust material procured from natural and plantation forest was carried out in consecutively sakuraba and blower kiln. The resulting sawdust charcoal was futher use for the manufacture of activated sawdust charcoal, while the accompanying wood vinegar was utilized for rice-field cultivation. The results are, as follows:

Integrated productions of charcoal and crude wood vinegar from natural and plantation forest's sawdust in sakuraba kiln were consecutively $292.68 \mathrm{~kg} /$ ton and $232.24 \mathrm{~kg} /$ ton. Meanwhile, the corresponding productions in blower kiln were higher, i.e. $344.76 \mathrm{~kg} /$ ton and $323.07 \mathrm{~kg} / \mathrm{ton}$, respectively. Yield of charcoal and crude wood vinegar from both mixed sawdust were similar to that of each kiln i.e 20.6 and 14.6\% (sakuraba); $19.3 \%$ and $22 \%$ (blower). Its integrated yield of sakuraba kiln was 35.2\% which is lower than blower kiln i.e $41.3 \%$.

The properties of charcoal from blower kiln were better than sakuraba kiln, with respect to lower ash content $(2,2 \%)$, lower volatile matter (11.9\%), and higher fixed carbon content (86,7\%). Yield of crude wood vinegar in blower kiln $(22 \%)$ more higher than sakuraba kiln (14.6\%). Crude wood vinegar from both kilns qualitatively contained similar chemicals components but quantitatively differed in component content, i.e acetic acid, methanol, phenol, acetyl, orto-cresol, para-creosol, furfural, apha-methyl-guaiaicol, cyclohexana.

Activated charcoal produced by soaking sawdust charcoal in $20 \%$ phosphoric acid, then treated with $695^{\circ} \mathrm{C}$ super heated water steam, and produced without H3PO4 soaking but with $605^{\circ} \mathrm{C}$ steam treatment afforded the iod-adsorption capacities (i.e. consecutively $857.7 \mathrm{mg} / \mathrm{g}$ and $789.7 \mathrm{mg} / \mathrm{g}$ ), which met the Indonesian National Standard requirement.

That achievement was due to insulating the outside activation-kiln wall with wool glass thereby reducing heat emission during the processing.

Use of $2.5 \%$ distilled wood vinegar added with NPK fertilizer for ciherang-variety rice cultivation produced dryunbusked rice (5.75 tons/ ha), quantitatively similar to using $2.5 \%$ organic fertilizer. Without NPK fertilizer, use of $2.5 \%$ wood vinegar afforded the bighest unbusked-rice production (4.41 tons/ ha), followed in decreasing order with organic fertilizer (4.10 tons/ ha) and control (3.21 tons/ ha). Use of 2.5\% distilled wood vinegar could indicatively function as fertilizer and induce effective rice-cultivation growth.
\end{abstract}

Keywords: Sawdust, charcoal, wood vinegar, activated charcoal, riceplant.

\footnotetext{
${ }^{1)}$ Peneliti pada Pusat Penelitian dan Pengembangan Hasil Hutan, Bogor

2) Teknisi pada Dinas Pertanian dan Kehutanan Kabupaten Bogor
} 


\begin{abstract}
ABSTRAK
Penelitian produksi terpadu arang dan cuka kayu menggunakan serbuk gergaji kayu campuran asal hutan alam dan hutan tanaman dilakukan pada tungku sakuraba dan tungku blower. Arang serbuk dimanfaatkan untuk bahan baku produksi arang aktif dan cuka kayunya untuk budidaya tanaman padi. Hasilnya sebagai berikut;

Produksi terpadu arang dan cuka kayu 'crude'dari serbuk gergaji kayu campuran hutan alam dan hutan tanaman pada tungku sakuraba masing-masing $292,68 \mathrm{~kg} /$ ton dan $232,24 \mathrm{~kg} /$ ton dan pada tungku blower $344,76 \mathrm{~kg} /$ ton dan $323,07 \mathrm{~kg} /$ ton. Rendemen arang dan cuka kayu ke dua jenis serbuk gergaji relatif sama pada masing-masing tungku yaitu 20,6 dan 14,6\% (sakuraba), 19,3\% dan 22\% (blower). Rendemen terpadunya pada tungku sakuraba 35,2\% menunjukkan angka lebih rendah dari blower 41,3\%. Oleh karena itu produksi terpadu pada tungku blower lebih baik dari sakuraba.

Sifat arang dari tungku blower lebih baik dari sakuraba ditunjukan oleh kadar abu $(2,2 \%)$ dan kadar zar mudah terbang $(11,9 \%)$ yang lebih rendah, dan kadar karbon tertambat (86,7\%) yang lebih tinggi. Cuka kayu 'crude' dari ke dua serbuk gergaji mengandung jenis komponen kimia yang sama pada kadar yang bervariasi, terdiri dari asam asetat, metanol, fenol, asetol, orto kreosol, para kreosol, furfural, alfa metil guaiakol, sikloheksana.

Produksi arang aktif memenuhi SNI pada parameter daya serap iod $(857,7 \mathrm{mg} / \mathrm{g})$ diperoleh dari perlakuan aktifasi perendaman asam fosfat $20 \%$ dan uap air pada suhu $695^{\circ} \mathrm{C}$ dan aktifasi dengan uap panas tanpa asam fosfat pada suhu $605^{\circ} \mathrm{C}(789,7 \mathrm{mg} /)$. Produksi arang aktif dengan mutu baik ini diperoleh setelah tungku aktifasi diredam emisi panasnya dengan gelas wol.

Pemanfaatan cuka kayu distilasi 2,5\% pada tanaman padi jenis ciherang dengan perlakuan penambahan pupuk NPK dapat menggantikan penggunaan bahan organik 2,5\% dengan hasil gabah kering giling yang sama yaitu 5,75 ton/ha. Perlakuan tanpa pupuk NPK menghasilkan gabah kering giling paling tinggi pada cuka kayu yaitu 4,41 ton/ha, bahan organik 4,10 ton / ha dan kontrol 3,21 ton/ha. Penggunaan cuka kayu distilat 2,5\% ini memberi petunjuk terhadap fungsinya sebagai pupuk dan merespon pertumbahan padi yang lebih baik.
\end{abstract}

Kata kunci: Serbuk gergaji kayu, tungku, arang, cuka kayu, arang aktif, padi.

\title{
I. PENDAHULUAN
}

Limbah komponen serbuk gergaji pada industri penggergajian kayu rendemennya 10,6\% menurut Martawijaya dan Sutigno (1990) serta 15\% (Anonim, 2000). Potensi limbah komponen serbuk gergaji setiap $\mathrm{m}^{3}$ dari input log kayu adalah $0,10-0,15 \mathrm{~m}^{3}$ dan dimanfaatkan antara lain untuk campuran obat nyamuk terutama serbuk gergaji jenis kayu jati, media tumbuh bibit bunga krisan dari serbuk gergaji jenis kayu sengon, media tumbuh jamur, bahan bakar rumah tangga, arang, briket arang, arang aktif dan arang kompos.

Limbah serbuk gergaji campuran kayu asal hutan alam secara industri telah dimanfaatkan sebagai bahan baku briket arang dengan produk sampingan cuka kayu. Tahapan teknik produksinya meliputi pengeringan serbuk gergaji, pembriketan serbuk gergaji kering pada suhu sekitar $220^{\circ} \mathrm{C}$ tanpa menggunakan bahan perekat, pengarangan briket kayu menjadi briket arang dan asap dari proses pengarangan dikondensasikan dengan cara sederhana menjadi cuka kayu 'crude' atau crude wood vinegar (Nurhayati, 2002). Ke dua produk, briket arang dan cuka kayu telah menjadi komoditas ekspor, akan tetapi pada saat ini industri tidak berproduksi sehubungan dengan menurunnya produksi kayu hutan alam. 
Produksi arang serbuk gergaji kayu campuran yang digunakan untuk arang aktif dan arang kompos tersebut di atas dilakukan pada tungku drum dan cara semi kontinyu (Gusmailina dkk, 2002) tanpa memproduksi cuka kayunya. Secara teknis, produksi arang serbuk gergaji kayu campuran dapat dipadukan dengan produksi cuka kayu antara lain dengan cara memodifikasi alat destilasi kering kayu dan merekayasa tungku 'portable' model Jepang.

Pemanfaatan arang serbuk gergaji yang bernilai tambah tinggi adalah untuk arang aktif. Harga jual arang aktif yang lebih tinggi dari arang dan penggunaannya diberbagai keperluan sebagai absorben merupakan salah satu alternatif dalam pengembangan pemanfaatan serbuk gergaji kayu campuran. Berbeda dengan arang aktif, pemanfaatan cuka kayu pada umumnya belum dikenal baik oleh masyarakat meskipun Indonesia dikenal sebagai pengekspor arang. Menurut Yatagai (2002), kebutuhan cuka kayu di Jepang berjumlah 8.000000 liter per tahun digunakan untuk budidaya tanaman pertanian, deodorant, pengusir binatang kecil, anti mikroba dan farmasi. Menurut Anonim (2002), komponen sebagian besar cuka kayu adalah air dan mengandung sekitar 200 jenis kompnen kimia, digunakan pada budidaya tanaman buah, bunga dan sayuran, cuka kayu encer disemprotkan pada daun tanaman membuat daun lebih sehat, cuka kayu dapat menggeser penggunaan pupuk kimia, 100\% pupuk alam, dapat mengurangi bau bila ditambahkan pada pupuk kandang dengan kualitas pupuk lebih baik.

Dalam penelitian ini serbuk gergaji kayu campuran dari industri penggergajian kayu hutan alam dan hutan tanaman digunakan sebagai bahan baku produksi arang terpadu dengan cuka kayunya menggunakan tungku blower dan sakuraba hasil rekayasa. Arang serbuk gergaji kayu campuran dimanfaatkan untuk produksi arang aktif menggunakan tungku aktifasi model pedesaan dengan menggunakan bahan bakar kayu dan cuka kayu dimanfaatkan pada budidaya tanaman padi dengan cara penyemprotan. Dalam tulisan ini disajikan hasil penelitian berupa informasi teknologi produksi dan pemanfaatan arang dan cuka kayu dalam upaya peningkatan nilai tambah penggunaan limbah komponen serbuk gergaji kayu campuran.

\section{BAHAN DAN METODE}

\section{A. Lokasi}

Limbah serbuk gergaji kayu campuran dari penggergajian kayu asal hutan alam (meranti merah, meranti putih, perupuk dll.) dan hutan tanaman (sengon, mangium, manii, jati, dll.) diambil dari industri penggergajian kayu di Jawa Barat. Penelitian dilakukan di Pusat Penelitian Hasil Hutan Bogor, Balai Penelitian Padi Sukamandi dan Balai Penelitian Bioteknologi Pertanian Bogor.

\section{B. Bahan dan Peralatan}

Limbah serbuk gergaji kayu campuran asal hutan tanaman dan hutan alam digunakan sebagai bahan baku produksi arang terpadu dengan cuka kayu. Produksi dilakukan pada 2 tungku yaitu tungku baja model tiup (blower) hasil rekayasa kapasitas $0,4 \mathrm{~m}^{3}$ dan tungku model sakuraba dari Jepang kapasitas $0,6 \mathrm{~m}^{3}$ masing-masing dilengkapi dengan unit pendingin air terdiri dari turen air, bak penampung, mesin otomatis untuk sirkulasi air. Bahan dan 
peralatan lain yang digunakan terdiri dari asam fosfat teknis, alat distilasi kapasitas 10 liter untuk menghasilkan cuka kayu distilat, kompresor, tungku arang aktif kapasitas $25 \mathrm{~kg}$ model pedesaan, kayu bakar, termometer, timbangan, oven, drum plastik dan lain-lain.

\section{Metode}

1. Produksi cuka kayu terpadu dengan arang

Serbuk gergaji kayu campuran hutan alam (sgha) dan hutan tanaman (sght) ditimbang kemudian dimasukkan ke dalam tungku yang sebelumnya telah dipasang bambu atau kayu bulat untuk membuat lubang jalur api. Serbuk gergaji dibakar dengan umpan kayu bakar pada dapur tungku. Nyala api dari kayu bakar menembus penyekat dan membakar serbuk gergaji. Termometer, pipa saluran air masuk dan air keluar dipasang. Suhu pembakaran diamati dan sirkulasi air ke pendingin diupayakan mengalir lancar. Proses pembakaran serbuk gergaji dalam tungku berlangsung tanpa kayu bakar karena proses pembakaran bersifat endotermis mulai pada suhu $220^{\circ} \mathrm{C}$. Produksi cuka kayu berakhir setelah suhu dalam tungku mencapai $350-400^{\circ} \mathrm{C}$, dengan cara menutup pipa saluran asap ke unit pendingin air dan membuka kran cerobong asap. Proses pembakaran tetap dilangsungkan untuk proses pemurnian arang dan berlangsung hingga suhu di atas $500^{\circ} \mathrm{C}$. Dengan cara demikian, komponen tar, zat volatile dan lain-lain yang terdapat pada arang akan terbakar dan arang yang dihasilkan termasuk kualitas arang yang baik digunakan untuk bahan baku arang aktif. Proses pemurnian berlangsung sekitar 3 - 5 jam dan berakhir pada suhu maksimal yaitu sekitar $520-640^{\circ} \mathrm{C}$. Cuka kayu yang dihasilkan sebagai cuka kayu 'crude' dan arang setelah dingin dikeluarkan dan ditimbang.

\section{Produksi arang aktif}

Produksi arang aktif baik dari arang sgha maupun sght aktifasinya dilakukan dengan perendaman dalam larutan asam fosfat 5\% selama 24 jam, kemudian ditiriskan hingga bebas air dan dipanaskan dalam tungku arang aktif sampai suhu $900^{\circ} \mathrm{C}$ selama 3 jam, dialiri dengan gas oksigen dari kompresor dan uap air. Proses aktifasi menggunakan kayu bakar. Metode yang sama dilakukan terhadap arang serbuk gergaji hutan tanaman dengan perendaman asam fosfat $20 \%$ setelah tungku aktifasi dibalut dengan wool glass untuk meredam emisi panas. Arang aktif setelah dingin dikeluarkan dari tungku dan ditimbang.

\section{Analisis arang, arang aktif dan cuka kayu}

Analisis arang dan arang aktif terdiri dari kadar air, kadar abu, zat mudah terbang dan daya serap menggunakan metode ASTM (1959) dan Standar Nasional Indonesia (Anonim, 1995). Analisis cuka kayu terdiri dari keasaman, berat jenis, warna, trasparansi dan bau mengikuti cara kerja Yatagai (2002) dan analisis komponen cuka kayu dilakukan di laboratorium Balai Bioteknologi Pertanian dengan metode gas chromatografi.

\section{Pemanfaatan cuka kayu}

Cuka kayu yang dipakai pada uji coba adalah cuka kayu distilasi pada konsentrasi 2,5\%. Uji coba dilakukan pada budidaya tanaman padi varietas ciherang di lokasi persawahan Balai Penelitian Padi Sukamandi seluas $2500 \mathrm{~m}^{2}$ dengan cara penyemprotan setelah padi berumur 1 
bulan tanam. Penyemprotan dilakukan selang 7 hari sampai masa panen dalam kurun waktu 3,5 bulan. Pelaksanaan uji coba mulai dari pengolahan tanah, pembibitan, pemupukan, penanaman, dan pengamatan pertumbuhan meliputi tinggi tanaman, jumlah gabah/malai, berat 1000 butir dan produksi gabah/panen yang dihitung sebagai gabah kering giling menggunakan metode baku yang dilakukan di Balai Penelitian Padi Sukamandi. Untuk mengetahui efektifitas pemanfaatan cuka kayu, dilakukan perlakuan penambahan pupuk NPK, tanpa NPK dan kontrol (tanpa NPK dan tanpa cuka kayu) dengan pembanding bahan organik $2,5 \%$.

\section{HASIL DAN PEMBAHASAN}

\section{A. Produksi Arang dan Cuka Kayu}

Serbuk gergaji kayu campuran dari hutan alam (sgha) dan hutan tanaman (sght) yang digunakan (Tabel 1) sebagai bahan baku produksi arang terpadu dengan cuka kayu berbeda pada kadar air. Kadar air sgha lebih rendah (16,60\%) dari sght (41,24\%). Perbedaan kadar air cenderung berpengaruh pada laju pembakaran serbuk gergaji menjadi arang. Laju pembakaran sgha pada tungku sakuraba dan blower masing-masing 3,413 kg/jam dan 4,770 $\mathrm{kg} / \mathrm{jam}$ dan sght pada masing-masing tungku 3,929 $\mathrm{kg} / \mathrm{jam}$ dan 5,958 kg/jam. Laju pembakaran sgha rata-rata 4,091 kg/jam menunjukkan angka lebih rendah dari laju pembakaran sght yaitu 4,943 kg/jam. Diantara ke dua tungku, laju pembakaran pada tungku sakuraba 3,671 kg/jam adalah dari laju pembakaran pada tungku blower yaitu 5,364 kg/jam. Hal ini memberi petunjuk bahwa serbuk gergaji pada kadar air yang rendah cenderung lebih mudah dan cepat terbakar daripada serbuk gergaji pada kadar air yang tinggi.

Proses pembakaran sgha dan sght pada tungku yang sama menunjukan pembakaran yang relatif sama; pada tungku sakuraba diperlukan waktu pembakaran selama 24 jam dan pada tungku blower 12 jam. Adanya perbedaan waktu proses pembakaran antara kedua tungku karena perbedaan konstruksi dan kapasitas (volume) tungku. Pada tungku sakuraba berlangsungnya proses pembakaran sesuai dengan pemasukan udara dari dapur api dimana besar kecilnya nyala api ditentukan oleh besar/kecilnya lubang udara pada dapur api. Pada tungku blower pemasukan udara kedalam tungku didrop dari tiupan udara asal mesin blower yang diatur secara stabil. Suhu akhir proses pembuatan arang serbuk gergaji pada tungku sakuraba $520^{\circ} \mathrm{C}$ dan $640^{\circ} \mathrm{C}$ dan tungku blow $575^{\circ} \mathrm{C}$ dan $640^{\circ} \mathrm{C}$.

Laju produksi arang sgha pada tungku sakuraba dan blower masing-masing 0,562 $\mathrm{kg} / \mathrm{jam}$ dan $0,781 \mathrm{~kg} / \mathrm{jam}$ dan laju produksi arang sght $0,537 \mathrm{~kg} / \mathrm{jam}$ dan $0,875 \mathrm{~kg} / \mathrm{jam}$. Laju produksi cuka kayu sgha pada tungku sakuraba dan blower masing-masing $0,437 \mathrm{~kg} / \mathrm{jam}$ dan $0,863 \mathrm{~kg} / \mathrm{jam}$ dan laju produksi arang sght masing-masing $0,537 \mathrm{~kg} / \mathrm{jam}$ dan $0,875 \mathrm{~kg} / \mathrm{jam}$. Laju produksi terpadu arang dan cuka kayu 'crude' dari sgha pada tungku sakuraba dan blow $0,999 \mathrm{~kg} / \mathrm{jam}$ dan 1,644 kg/jam dan laju produksi dari sght 0,912 kg/jam dan 1,925 kg/jam. Laju produksi arang pada tungku blower menunjukkan laju produksi lebih tinggi dari sakuraba. 
Tabel 1. Produksi arang dan cuka kayu "crude"

Table 1. Charcoal and crude wood vinegar production

\begin{tabular}{|c|c|c|c|c|}
\hline \multirow[t]{2}{*}{ Parameter } & \multicolumn{2}{|c|}{$\begin{array}{l}\text { Serbuk gergaji dari hutan alam } \\
\text { (Sawdust of natural forest), Sgha }\end{array}$} & \multicolumn{2}{|c|}{$\begin{array}{c}\text { Serbuk gergaji dari hutan } \\
\text { tanaman (Sawdust of plantation } \\
\text { forest), Sght }\end{array}$} \\
\hline & Sakuraba & Blower & Sakuraba & Blower \\
\hline $\begin{array}{l}\text { Kadar air berat kering } \\
\text { oven (Moisture content of } \\
\text { oven dry weight), } \%\end{array}$ & 16,6 & 16,6 & 51,9 & 30,5 \\
\hline $\begin{array}{l}\text { Berat serbuk gergaji } \\
\text { (Sawdust weight), kg }\end{array}$ & 82 & 52,5 & 94,3 & 71,5 \\
\hline $\begin{array}{l}\text { Berat serbuk gergaji } \\
\text { kering tanur (Weight of } \\
\text { oven dry sawdust), kg }\end{array}$ & 71,1 & 45,0 & 62,1 & 54,8 \\
\hline $\begin{array}{l}\text { Kayu bakar (Fuel-wood), } \\
\text { kg }\end{array}$ & 8 & 5 & 8,5 & 7 \\
\hline $\begin{array}{l}\text { Suhu pengarangan } \\
\text { (Carbonization } \\
\text { temperature), }{ }^{\circ} \mathrm{C}\end{array}$ & 520 & 640 & 640 & 575 \\
\hline $\begin{array}{l}\text { Lama (Duration), jam } \\
\text { (hour) }\end{array}$ & 24 & 11 & 24 & 12 \\
\hline $\begin{array}{l}\text { Berat arang (Weight of } \\
\text { charcoal), kg }\end{array}$ & 13,50 & 8,60 & 12,90 & 10,50 \\
\hline $\begin{array}{l}\text { Berat cuka kayu (Weight } \\
\text { of wood vinegar), } \mathrm{kg}\end{array}$ & 10,50 & 9,50 & 9 & 12,60 \\
\hline $\begin{array}{l}\text { Laju pembakaran } \\
\text { serbuk gergaji (Burning } \\
\text { flow of sawdust), } \mathrm{kg} / \mathrm{jam} \\
\text { (bours) }\end{array}$ & 3,413 & 4,770 & 3,929 & 5,958 \\
\hline $\begin{array}{l}\text { Laju produksi arang } \\
\text { (Production flow of } \\
\text { Charcoal), kg/jam (hours) }\end{array}$ & 0,562 & 0,781 & 0,537 & 0,875 \\
\hline $\begin{array}{l}\text { Laju produksi cuka } \\
\text { kayu crude (Production } \\
\text { flow of crude wood vinegar), } \\
\mathrm{kg} / \mathrm{jam} \text { (hours) }\end{array}$ & 0,437 & 0,863 & 0,375 & 1,050 \\
\hline $\begin{array}{l}\text { Produksi arang per ton } \\
\text { serbuk gergaji (Charcoal } \\
\text { production of per ton } \\
\text { sawdust), } \mathrm{kg} / \mathrm{ton}\end{array}$ & 164,63 & 163,81 & 136,80 & 146,85 \\
\hline $\begin{array}{l}\text { Produksi cuka kayu per } \\
\text { ton serbuk gergaji } \\
\text { (Wood vinegar produ ction } \\
\text { of per ton sawdust), } \\
\mathrm{kg} / \text { ton }\end{array}$ & 128,05 & 180,95 & 95,44 & 176,22 \\
\hline
\end{tabular}


Produksi arang per ton serbuk gergaji (kg/ton) dari sgha lebih tinggi dari sght pada tungku yang sama, demikian pula produksi cuka kayunya. Produksi arang per ton serbuk gergaji untuk sgha pada tungku sakuraba dan blow masing-masing yaitu 164,63 kg/ton dan $163,81 \mathrm{~kg} /$ ton , sedang arang sght 136,80 kg/ton dan 146,85 kg/ton. Produksi cuka kayu per ton serbuk gergaji untuk sgha pada tungku sakuraba dan blower masing-masing 128,05 $\mathrm{kg} /$ ton dan 180,95 kg/ton, sedang sght $95,44 \mathrm{~kg} /$ ton dan $176,22 \mathrm{~kg} /$ ton.

Di antara penggunaan kedua tungku tersebut menunjukkan bahwa tungku blower lebih baik dari tungku sakuraba baik untuk produksi arang maupun produksi cuka kayunya.

Produksi terpadu arang dan cuka kayu dari sgha pada tungku sakuraba 292,68 kg/ton dan pada tungku blower $344,76 \mathrm{~kg} /$ ton dan dari sght pada tungku sakuraba 232,24 kg/ton, $3,413 \mathrm{~kg} / \mathrm{jam}$ dan 4,770 kg/jam dan sght pada masing-masing tungku 3,929 kg/jam dan 5,958 $\mathrm{kg} /$ jam. Laju pembakaran sgha rata-rata $4,091 \mathrm{~kg} / \mathrm{jam}$ menunjukan angka lebih rendah dari laju pembakaran sght rata-rata 4,943 kg/jam. Diantara ke dua tungku, laju pada tungku blower $323,07 \mathrm{~kg} /$ ton. Produksi terpadu pada tungku blower lebih tinggi dari tungku sakuraba. Dihubungkan dengan potensi limbah komponen serbuk gergaji kayu campuran pada industri penggergajian kayu $(0,10-1,15 \mathrm{~m} 3)$ dan pemanfaatannya untuk bahan baku produksi terpadu arang dan cuka kayu, dihasilkan arang antara 3,4 - 5,1 kg dan cuka kayu antara 4,1 - 6,1 kg untuk setiap m3 dari input log kayu dengan asumsi kerapatan $0,23 \mathrm{~g} / \mathrm{cm} 3$ dan produksi menggunakan tungku blower.

\section{B. Rendemen dan Sifat Arang}

Rendemen serbuk gergaji sgha dan sght (Tabel 2) yang dihitung dari berat kayu kering (rata-rata 19,8\%) menunjukan rendemen yang relatif sama pada masing-masing tungku blower dan sakuraba. Bila dihitung dari berat kayu basah rendemen arang sgha lebih tinggi dari sght yaitu 16.4\% lebih tinggi dari 14.2\%. Dibandingkan dengan rendemen serbuk gergaji kayu campuran (15\%) yang diproduksi pada tungku Mark V kapasitas 2,5 m3 (Anonim, 1980), maka rendemen sgha dan sght hasil penelitian menunjukan rendemen yang lebih tinggi.

Sifat arang sgha dan sght menunjukan sifat yang relatif berbeda pada penggunaan tungku. Sifat arang dari tungku blower lebih baik dari tungku sakuraba dan ini ditunjukan oleh kadar abu dan kadar zar mudah terbang yang lebih rendah, kadar karbon tertambat lebih tinggi. Pada tungku blower kadar abu rata-rata 2,2\%, kadar zat mudah terbang $12,5 \%$ dan kadar karbon tertambat $86,7 \%$ sedang pada tungku sakuraba kadar abu 5,8\%, kadar zat mudah terbang $15,9 \%$ dan kadar karbon tertambat $82 \%$. Sifat daya serap iod antara 192,9 $321,1 \mathrm{mg} / \mathrm{g}$, yang terendah terdapat pada tungku blower dari sght dan tertinggi terdapat pada tungku sgha pada tungku sakuraba. Daya serap iod (Tabel 2) menunjukan kecenderungan bahwa daya serap arang serbuk gergaji yang dihasilkan dari tungku blower lebih rendah dari tungku sakuraba.

Produksi arang sgha dan sght tersebut diatas menunjukan sifat arang yang baik untuk digunakan sebagai bahan baku pembuatan arang aktif karena memenuhi persyaratan bahan baku arang aktif diantaranya kadar air pada kisaran 3 - 10\%, zat mudah terbang 15 - 20\% dan kadar karbon tertambat $70-80 \%$ (Milan \& Stasky dalam Nurhayati, 1985). 


\section{Rendemen dan Sifat Cuka Kayu}

Rendemen cuka kayu'crude' rata-rata dari sgha dan sght pada masing-masing tungku sakuraba dan blower menunjukan rendemen relatif sama (Tabel 2), akan tetapi rendemen ini berbeda pada penggunaan tungku. Rendemen cuka kayu'crude' pada tungku blower $(22 \%)$ lebih tinggi dari tungku sakuraba (14,6\%) dihitung dari berat kayu kering. Bila dibandingkan dengan rendemen cuka kayu dari industri briket arang (16\%), rendemen cuka kayu sgha pada tungku blower adalah lebih tinggi dari industri itu sedang rendemen cuka kayu sght lebih rendah.

Tabe1 2. Rendemen dan sifat arang Table 2. Yield and charcoal properties

\begin{tabular}{|l|c|c|c|c|}
\hline \multirow{2}{*}{$\begin{array}{c}\text { Jenis analisis } \\
\text { Kind of analysis) }\end{array}$} & \multicolumn{2}{|c|}{$\begin{array}{c}\text { Serbuk gergaji hutan alam } \\
\text { (Sawdust of natural forest), Sgha }\end{array}$} & \multicolumn{2}{|c|}{$\begin{array}{c}\text { Serbuk gergaji hutan tanaman } \\
\text { (Sawdust of plantation forest), Sght }\end{array}$} \\
\cline { 2 - 5 } & Sakuraba & Blower & Sakuraba & Blower \\
\hline $\begin{array}{l}\text { Rendemen dari } \\
\text { berat kering oven } \\
\text { (Yield of oven dry } \\
\text { weight), \% }\end{array}$ & 20,4 & 19,1 & 20,9 & 19,2 \\
\hline $\begin{array}{l}\text { Rendemen dari } \\
\text { berat basah (Yield } \\
\text { of wet weight), \% }\end{array}$ & 16,5 & 16,4 & 13,7 & 14,7 \\
\hline $\begin{array}{l}\text { Kadar air (Mois- } \\
\text { ture content), \% }\end{array}$ & 5,6 & 2,5 & 1,5 & 4 \\
\hline $\begin{array}{l}\text { Kadar abu (Ash } \\
\text { content), \% }\end{array}$ & 4,2 & 2,4 & 5,8 & 12,6 \\
\hline $\begin{array}{l}\text { Kadar zat mudah } \\
\text { terbang (Volatile } \\
\text { matter content), \% }\end{array}$ & 13,9 & 11,2 & 15,9 & 85,9 \\
\hline $\begin{array}{l}\text { Kadar karbon } \\
\text { tertambat (Fix } \\
\text { carbon content), \% }\end{array}$ & 82 & 86,4 & 78,3 & 192,9 \\
\hline $\begin{array}{l}\text { Daya serap iod } \\
\text { (Iod absorption), } \\
\text { mg/g }\end{array}$ & 321,1 & 229,8 & 260,6 & \\
\hline
\end{tabular}

Sifat berat jenis, warna, bau dan transparansi menunjukkan sifat cuka kayu yang sama antara kedua jenis serbuk gergaji. Komponen kimia cuka kayu yang tercantum pada Tabel 4 terdiri dari asam asetat, methanol, fenol, asetol, kreosol, furfural, metilguaiakol dan sikloheksana terdapat pada masing-masing sgha dan sght dengan kadar komponen yang bervariasi. Komponen kimia cuka kayu sgha dan sght menunjukkan kadar asam asetat antara 7,121 - 9,971 ppm, metanol 2,086 - 3,543 ppm, fenol 1,495 - 2,200 ppm, asetol 0,309 -0,828 ppm, orto kreosol 2,391 - 2,598 ppm, para kreosol 1,110 - 2,183 ppm, furfural 1,393 - 2,054 ppm, alfa metilguaiakol 1,697 - 2,300 ppm, sikloheksana 1,039 - 1,443 ppm. Pada umumnya 
kadar komponen kimia cuka kayu shga dari tungku sakuraba menunjukkan nilai ppm relatif lebih tinggi dari cuka kayu sght tungku blower. Variasi kadar komponen kimia ini mungkin disebabkan oleh jenis serbuk dan suhu karbonisasi yang berbeda seperti tercantum pada Tabel 1.

Tabel 3. Rendemen dan sifat cuka kayu "crude" Table3. Yield and crude wood vinegar properties

\begin{tabular}{|c|c|c|c|c|c|}
\hline \multirow[t]{2}{*}{$\begin{array}{l}\text { Jenis analisis } \\
\text { (Kinds of analysis) }\end{array}$} & \multicolumn{2}{|c|}{$\begin{array}{c}\text { Serbuk gergaji hutan alam } \\
\text { (Sawdust of natural forest), } \\
\text { Sgha }\end{array}$} & \multicolumn{2}{|c|}{$\begin{array}{l}\text { Serbuk gergaji hutan } \\
\text { tanaman (Sawdust of } \\
\text { plantation forest), Sght }\end{array}$} & \multirow[t]{2}{*}{$\begin{array}{c}\text { Mutu cuka kayu } \\
\text { Jepang (Quality } \\
\text { of Japan wood } \\
\text { vinegar) }\end{array}$} \\
\hline & Sakuraba & Blower & Sakuraba & Blower & \\
\hline $\begin{array}{l}\text { Rendemen dari } \\
\text { berat kering (Yield } \\
\text { of dry weight), } \%\end{array}$ & 14,8 & 21,1 & 14,5 & 23 & \\
\hline $\begin{array}{l}\text { Rendemen dari } \\
\text { berat basah (Yield } \\
\text { of wet weight), \% }\end{array}$ & 12,8 & 18,1 & 9,5 & 17,6 & \\
\hline $\begin{array}{l}\text { Keasaman } \\
(\text { Acidity }), \mathrm{pH}\end{array}$ & 4,3 & 4,7 & 4,3 & 4,3 & $1,5-3,7$ \\
\hline $\begin{array}{l}\text { Berat jenis (Spesific } \\
\text { gravity) }\end{array}$ & 1,004 & 1,018 & 1,013 & 1,012 & $>1,005$ \\
\hline Bau (Smell) & $\begin{array}{l}\text { Lemah } \\
\text { (Weak) }\end{array}$ & $\begin{array}{l}\text { Lemah } \\
\text { (Weak) }\end{array}$ & $\begin{array}{l}\text { Lemah } \\
\text { (Weak) }\end{array}$ & $\begin{array}{l}\text { Agak kuat } \\
\text { (Little } \\
\text { strong) }\end{array}$ & \\
\hline Warna (Colour) & $\begin{array}{l}\text { Coklat } \\
\text { kehitaman } \\
\text { (Brown- } \\
\text { blackish) }\end{array}$ & $\begin{array}{l}\text { Coklat } \\
\text { kehitaman } \\
\text { (Brown- } \\
\text { blackish) }\end{array}$ & $\begin{array}{l}\text { Coklat } \\
\text { kehitaman } \\
\text { (Brown- } \\
\text { blackish) }\end{array}$ & $\begin{array}{l}\text { Coklat } \\
\text { kehitaman } \\
\text { Brown } \\
\text { (Brown - } \\
\text { blackish - } \\
\text { blackish) }\end{array}$ & $\begin{array}{l}\text { Kuning - } \\
\text { coklat } \\
\text { kemerahan } \\
\text { (Yellow-reddish } \\
\text { brown) }\end{array}$ \\
\hline $\begin{array}{l}\text { Transparansi } \\
\text { (Transparancy) }\end{array}$ & $\begin{array}{l}\text { Ada } \\
\text { suspensi } \\
\text { (Suspension) }\end{array}$ & $\begin{array}{l}\text { Ada } \\
\text { suspensi } \\
\text { (Suspension) }\end{array}$ & $\begin{array}{l}\text { Ada } \\
\text { suspensi } \\
\text { (Suspension) }\end{array}$ & $\begin{array}{l}\text { Ada } \\
\text { suspensi } \\
\text { (Suspnsion) }\end{array}$ & $\begin{array}{l}\text { Tidak keruh, } \\
\text { tidak ada sus- } \\
\text { pensi (No } \\
\text { cloud, no } \\
\text { suspension) }\end{array}$ \\
\hline
\end{tabular}

Menurut Yatagai (2002) komponen kimia cuka kayu seperti asam asetat berfungsi pada pertumbuhan tanaman sebagai pemercepat pertumbuhan dan pencegahan penyakit tanaman, metanol sebagai pemercepat pertumbuhan, fenol dan turunannya sebagai inhibitor atau pencegah hama dan penyakit serta senyawaan netral sebagai pemercepat pertumbuhan tanaman. Gambaran ini memberi arti bahwa cuka kayu sght dan sgha memiliki fungsi sama sebagai pemercepat pertumbuhan, inhibitor, pupuk alam, cuka kayu encer disemprotkan pada daun tanaman membuat daun lebih sehat, cuka kayu dapat menggeser penggunaan pupuk kimia, 100\% pupuk alam (Anonim, 2002). 
Tabel 4. Analisis komponen kimia cuka kayu "crude" Table 4. Chemical component analysis of crude wood vinegar

\begin{tabular}{|l|c|c|c|c|}
\hline \multirow{2}{*}{$\begin{array}{c}\text { Jenis analisis (Kinds of analysis), } \\
\text { (Part per million, ppm) }\end{array}$} & \multicolumn{2}{|c|}{$\begin{array}{c}\text { Serbuk gergaji hutan alam } \\
\text { (Sawdust of natural forest), } \\
\text { Sgha }\end{array}$} & \multicolumn{2}{|c|}{$\begin{array}{c}\text { Serbuk gergaji hutan } \\
\text { tanaman (Sawdust of } \\
\text { plantation forest, Sght }\end{array}$} \\
\cline { 2 - 5 } & Sakuraba & Blower & Sakuraba & Blower \\
\hline Asam asetat (Acetic acid) & 9,971 & 7,877 & 7,351 & 7,121 \\
\hline Metanol (Methanol) & 3,543 & 2,328 & 2,886 & 2,086 \\
\hline Fenol (Phenol) & 2,200 & 1,495 & 1,972 & 1,507 \\
\hline Asetol (Acetol) & 0,828 & 0,813 & 0,533 & 0,309 \\
\hline O-kreosol (O-creosol) & 2,598 & 2,431 & 2,391 & 2,418 \\
\hline P-kreosol (P-creosol) & 2,183 & 1,819 & 2,703 & 1,110 \\
\hline Furfural & 2,054 & 1,680 & 1,529 & 1,393 \\
\hline A-metilguiakol (A-methylguaiaco) & 2,300 & 1,830 & 1,697 & 1,772 \\
\hline Sikloheksana (Cyclohexane) & 1,443 & 1,039 & 1,347 & 1,217 \\
\hline
\end{tabular}

Sifat cuka kayu 'crude' sgha dan sght yang didistilasi pada suhu sekitar $100^{\circ} \mathrm{C}$ yang tercantum pada Tabel 5 menunjukan sifat yang sama untuk parameter $\mathrm{pH}$, berat jenis, bau, warna dan transparansi. Rendemen cuka kayu distilasi sekitar 95\% dari cuka kayu 'crude'. Cuka kayu distilasi sgha dan sght ini memenuhi mutu cuka kayu standar Jepang untuk semua paramter sedang cuka kayu 'crude' tidak memenuhi mutu Jepang pada parameter warna dan transparansi.

\section{Produksi Arang Aktif}

Kayu bakar yang digunakan rata-rata $8,67 \mathrm{~kg}$ per gram arang untuk proses aktifasi selama 3 jam (Tabel 6). Suhu aktifasi tertinggi $670^{\circ} \mathrm{C}$ pada arang sgha dari tungku sakuraba dan yang terendah $595^{\circ} \mathrm{C}$ pada arang sght dari tungku blower. Aktifasi arang sgha berlangsung pada suhu 670 dan $605^{\circ} \mathrm{C}$ dan aktifasi arang sght yaitu pada suhu 595 dan $590^{\circ} \mathrm{C}$. Suhu aktifasi ini adalah suhu aktifasi maksimum yang dapat dicapai pada tungku arang aktif dengan bahan bakar kayu. Berbeda dengan produksi arang aktif serbuk gergaji yang menggunakan pemanas listrik, suhu yang dapat dicapai pada kisaran $650-850^{\circ} \mathrm{C}$ (Hendra, 2006) sedang suhu aktifasi pada tungku model pedesaan pada kisaran $595-670^{\circ} \mathrm{C}$.

Rendemen arang aktif sgha dan sght dihitung dari serbuk gergaji berat kering menunjukan rendemen relatif sama yaitu 10\%. Rendemen arang dari kayu mula-mula sekitar $20 \%$ setelah menjadi arang aktif rendemennya berkurang menjadi 10\%. Akan tetapi rendemen arang aktif dihitung dari berat arang menunjukan perbedaan antara sgha dan sght, dimana arang aktif sgha relatif lebih tinggi dari sght masing-masing 78,9 dan $64,7 \%$. Rendemen arang aktif ini relatif sama dengan rendemen arang aktif serbuk gergaji campuran (76,7 dan $63,3 \%$ ) yang diaktifasi masing-masing pada suhu 650 dan $750^{\circ} \mathrm{C}$ menggunakan asam fosfat $10 \%$ (Hendra, 2006). 


\section{Tabel 5. Sifat cuka kayu hasil distilasi}

\section{Table 5. Distilled wood vinegar properties}

\begin{tabular}{|c|c|c|c|c|c|}
\hline \multirow[t]{2}{*}{$\begin{array}{l}\text { Jenis analisis } \\
\text { (Kinds of ana- } \\
\text { lysis) }\end{array}$} & \multicolumn{2}{|c|}{$\begin{array}{c}\text { Serbuk gergaji hutan alam } \\
\text { (Sawdust of natural forest), } \\
\text { Sgha }\end{array}$} & \multicolumn{2}{|c|}{$\begin{array}{c}\text { Serbuk gergaji hutan tanaman } \\
\text { (Sawdust of plantation forest), } \\
\text { Sght }\end{array}$} & \multirow[t]{2}{*}{$\begin{array}{l}\text { Mutu distilasi } \\
\text { cuka kayu } \\
\text { Jepang (Quality } \\
\text { of Japan distilled } \\
\text { wood vinegar) }\end{array}$} \\
\hline & Sakuraba & Blower & Sakuraba & Blower & \\
\hline $\begin{array}{l}\text { Keasaman } \\
(\text { Acidity), } \mathrm{pH}\end{array}$ & 3,32 & 3,39 & 3,45 & 3,41 & $1,5-3,7$ \\
\hline $\begin{array}{l}\text { Berat jenis } \\
\text { (Spesific } \\
\text { gravity) }\end{array}$ & 0,9947 & 0,9948 & 0,9950 & 0,9950 & $1,001<$ \\
\hline $\begin{array}{l}\text { Bau } \\
\text { (Smell) }\end{array}$ & $\begin{array}{l}\text { Lemah } \\
\text { (Weak) }\end{array}$ & $\begin{array}{l}\text { Lemah } \\
\text { (Weak) }\end{array}$ & $\begin{array}{l}\text { Lemah } \\
\text { (Weak) }\end{array}$ & $\begin{array}{l}\text { Agak kuat } \\
\text { (Rather strong) }\end{array}$ & \\
\hline $\begin{array}{l}\text { Warna } \\
\text { (Colour) }\end{array}$ & $\begin{array}{l}\text { Kuning pucat } \\
\text { (Pale yellow) }\end{array}$ & $\begin{array}{l}\text { Kuning pucat } \\
\text { (Pale yellow) }\end{array}$ & $\begin{array}{l}\text { Kuning pucat } \\
\text { (Pale yellow) }\end{array}$ & $\begin{array}{l}\text { Kuning agak } \\
\text { keruh (Rather } \\
\text { dark of yellow) }\end{array}$ & $\begin{array}{l}\text { Kuning pucat } \\
\text {-coklat } \\
\text { kemerahan } \\
\text { (Pale yellow- } \\
\text { reddish brown) }\end{array}$ \\
\hline $\begin{array}{l}\text { Transparansi } \\
\text { (Transparancy) }\end{array}$ & $\begin{array}{l}\text { Tidak } \\
\text { suspensi (No } \\
\text { suspension) }\end{array}$ & $\begin{array}{l}\text { Tidak } \\
\text { suspensi (No } \\
\text { suspension) }\end{array}$ & $\begin{array}{l}\text { Tidak } \\
\text { suspensi (No } \\
\text { suspension) }\end{array}$ & $\begin{array}{l}\text { Tidak } \\
\text { suspensi (No } \\
\text { suspension) }\end{array}$ & $\begin{array}{l}\text { Tidak keruh, } \\
\text { ada suspensi } \\
\text { (No cloud, no } \\
\text { suspension) }\end{array}$ \\
\hline
\end{tabular}

Sifat arang aktif sght dari perlakuan perendaman asam fosfat $5 \%$ dan uap air menunjukkan rendemen dan kadar air yang sama dengan perlakuan yang hanya menggunakan uap air saja. Kadar abu dan daya serap iod lebih tinggi tetapi kadar zat mudah terbang dan kadar karbon tertambat lebih rendah. Kualitas arang aktif yang dihasilkan pada penelitian ini tidak memenuhi mutu arang aktif Standar Nasional Indonesia (SNI, 1995), hal ini ditunjukan oleh sifat daya serap iod yang rendah yaitu antara $385,5-556,6 \mathrm{mg} / \mathrm{g}$, sedang syarat daya serap SNI $750 \mathrm{mg} / \mathrm{g}$.

Peningkatan sifat daya serap iod dari arang aktif ini menunjukan peningkatan daya serap iod yang rendah. Daya serap iod arang sekitar 192,9 - 321,1 mg/g dan setelah diaktifasi menjadi arang aktif daya serapnya menjadi $385,5-556,6 \mathrm{mg} / \mathrm{g}$. Daya serap tertinggi terdapat pada arang aktif sgha dari tungku blower dan yang terendah terdapat pada sght dari tungku sakuraba.

Pada Tabel 8 tercantum hasil aktifasi dari arang sght tungku blower dengan perlakuan aktifasi asam fosfat teknis $20 \%$ dan uap air serta aktifasi tanpa asam fosfat $20 \%$ dan uap air. Aktifasi dilakukan pada tungku yang sama dengan aktifasi tersebut diatas (Tabel 6), bedanya pada aktifasi ini tungku arang aktif pedesaan dibalut lebih dahulu dengan wool glass untuk meredam emisi panas. Penggunaan asam fosfat dari 5\% ke 20\% didasarkan atas hasil percobaan pendahuluan skala laboratorium pada beberapa konsentrasi asam fosfat.

Rendemen arang aktif dan kadar zat mudah terbang dari aktifasi asam fosfat $20 \%$ dan uap air pada Tabel 9 relatif sama dengan rendemen dan kadar zat mudah terbang arang aktif sgha dari tungku blower pada Tabel 7 akan tetapi daya serap iod lebih tinggi pada Tabel 9. 
Tabel 6. Produksi arang aktif dari arang serbuk gergaji kayu campuran Table 6. Activated charcoal production of mixture sawdust charcoal

\begin{tabular}{|l|c|c|c|c|}
\hline \multirow{2}{*}{$\begin{array}{c}\text { Jenis analisis } \\
\text { (Kinds of analysis) }\end{array}$} & \multicolumn{2}{|c|}{$\begin{array}{c}\text { Serbuk gergaji hutan alam } \\
\text { (Sawdust of natural forest), Sgha }\end{array}$} & $\begin{array}{c}\text { Serbk gergaji hutan tanaman } \\
\text { (Sawdust of plantation forest), } \\
\text { Sght }\end{array}$ \\
\cline { 2 - 5 } & Sakuraba & Blower & Sakuraba & Blower \\
\hline $\begin{array}{l}\text { Berat arang (Charcoal } \\
\text { weight), kg }\end{array}$ & 8,5 & 7,5 & 8,5 & 9,5 \\
\hline Kayu bakar (Fuelwood), kg & 75 & 73 & 70 & 72 \\
\hline $\begin{array}{l}\text { Jumlah uap air (Total of } \\
\text { steam), liter }\end{array}$ & 7,5 & 8,5 & 9 & 7,5 \\
\hline $\begin{array}{l}\text { Lama aliran uap air } \\
\text { (Duration of steam flow), } \\
\text { menit (minute) }\end{array}$ & 180 & 180 & 180 & 180 \\
\hline $\begin{array}{l}\text { Suhu aktifasi (Activation } \\
\text { temperature), }{ }^{\circ} \text { C. }\end{array}$ & 670 & 605 & 595 & 590 \\
\hline $\begin{array}{l}\text { Berat arang aktif (Weight } \\
\text { of activated charcoal), kg }\end{array}$ & 7,1 & 5,5 & 5,1 & 6,5 \\
\hline
\end{tabular}

Daya serap iod arang sght mula-mula $192,9 \mathrm{mg} / \mathrm{g}$ setelah menjadi arang aktif daya serap iodnya 469,9 mg/g kemudian meningkat menjadi $857,7 \mathrm{mg} / \mathrm{g}$ dan 798,7 mg/g.

Peningkatan daya serap iod ini masing-masing dihasilkan dari perendaman asam fosfat $20 \%$ aktifasi suhu $695^{\circ} \mathrm{C}$ dengan uap air dan aktifasi pada suhu $605^{\circ} \mathrm{C}$ dengan uap air tanpa asam fosfat $20 \%$. Sifat arang aktif untuk semua parameter kecuali kadar abu memenuhi persyaratan arang aktif Standar Nasional Indonesia (SNI, 1995).

\section{E. Pemanfaatan Cuka Kayu}

Pemanfaatan cuka kayu distilasi 2,5\% pada tanaman padi jenis varietas ciherang dengan perlakuan penambahan NPK dan tanpa NPK yang disemprotkan sebanyak 8 kali setelah umur padi 1 bulan dengan pembanding bahan organik 2,5\% dan kontrol dengan respon terhadap tinggi tanaman, jumlah gabah per malai, bobot $1000 \mathrm{~g}$ butir dan gabah kering giling hasilnya tercantum pada Tabel 10.

Penggunaan cuka kayu distilat 2,5\% pada perlakuan penambahan pupuk NPK menghasilkan tinggi tanaman yang paling tinggi $(62,1 \mathrm{~cm})$ dibandingkan dengan kontrol $(57,4$ $\mathrm{cm})$ ) sebaliknya dengan perlakuan tanpa NPK penggunaan cuka kayu ini menunjukkan hasil paling rendah $(54,7 \mathrm{~cm})$ dibandingkan dengan kontrol $(56 \mathrm{~cm})$. Penggunaan cuka kayu distilat 2,5\% pada perlakuan penambahan pupuk NPK dan tanpa NPK menghasilkan jumlah gabah/malai dan gabah kering giling paling tinggi dibandingkan dengan kontrol.

Pada perlakuan penambahan NPK, penggunaan cuka kayu distilat 2,5\% dan bahan organik 2,5\% menghasilkan tinggi tanaman, bobot 1000 butir dan gabah kering giling yang relatif sama, artinya cuka kayu distilat 2,5\% dapat menggantikan penggunaan bahan organik $2,5 \%$ dengan hasil gabah kering giling yang sama yaitu 5,77 ton/ha. Diantara penggunaan cuka kayu distilat 2,5\% dan bahan organik 2,5\% pada perlakuan tanpa pupuk NPK, cuka kayu 
Tabel 7. Sifat arang aktif Table 7. Activated charcoal properties

\begin{tabular}{|l|c|c|c|c|}
\hline \multicolumn{1}{|c|}{$\begin{array}{c}\text { Jenis analisis } \\
\text { (Kinds of analysis) }\end{array}$} & \multicolumn{2}{|c|}{$\begin{array}{c}\text { Serbuk gergaji hutan alam } \\
\text { (Sawdust of natural forest), Sgha }\end{array}$} & $\begin{array}{c}\text { Serbk gergaji hutan tanaman } \\
\text { (Sawdust of plantation forest), } \\
\text { Sght }\end{array}$ \\
\cline { 2 - 5 } & Sakuraba & Blower & Sakuraba & Blower \\
\hline $\begin{array}{l}\text { Rendemen dari arang } \\
\text { (Yield of charcoal sawdust), } \\
\%\end{array}$ & 83,5 & 73,3 & 60 & 68,4 \\
\hline $\begin{array}{l}\text { Rendemen dari serbuk } \\
\text { gergaji kering tanur (Yiled } \\
\text { of oven dry sawdust) \% }\end{array}$ & 10 & 10 & 8,2 & 11,9 \\
\hline $\begin{array}{l}\text { Rendemen dari serbuk } \\
\text { gergaji basah (Yield of wet } \\
\text { sawdust), \% }\end{array}$ & 8,7 & 7,7 & 5,4 & 9,1 \\
\hline $\begin{array}{l}\text { Kadar air (Moisture } \\
\text { content), \% }\end{array}$ & 4,9 & 2,9 & 11,3 & 10,7 \\
\hline $\begin{array}{l}\text { Kadar abu (Ash content), } \\
\%\end{array}$ & 5,8 & 4,6 & 7,3 & 9,8 \\
\hline $\begin{array}{l}\text { Kadar zat mudah terbang } \\
\text { (Volatile matter content), \% }\end{array}$ & 10,1 & 7,9 & 10,4 & 10,6 \\
\hline $\begin{array}{l}\text { Kadar karbon tertambat } \\
\text { (Fixed carbon content), \% }\end{array}$ & 84,0 & 87,4 & 81,9 & 79,7 \\
\hline $\begin{array}{l}\text { Daya serap iod (Iod } \\
\text { absorption), mg/g }\end{array}$ & 454,7 & 556,6 & 385,5 & 469,9 \\
\hline $\begin{array}{l}\text { Daya serap benzene } \\
\text { (Benzena absorption), \% }\end{array}$ & 10,9 & 12,2 & 8,4 & 8,1 \\
\hline
\end{tabular}

distilat menghasilkan jumlah malai dan hasil gabah kering giling yang lebih tinggi. Hal yang sama dibandingkan dengan kontrol, penggunaan cuka kayu distilat 2,5\% menghasilkan gabah kering giling yang lebih tinggi pula yaitu $4,41>3,31$ ton/ha. Selisih gabah kering giling sebanyak 0,98 ton/ha antara cuka kayu distilat 2,5\% dan kontrol serta selisih 0,31 ton/ha antara cuka kayu distilat dan bahan organik 2,5\% memberi petunjuk bahwa cuka kayu distilat 2,5\% diperkirakan mengandung komponen penyubur tanaman, pupuk NPK, unsur hara dan mikro.

Pemanfaatan cuka kayu distilat yang memberi respon baik terhadap pertumbuhan padi tersebut diatas adalah sesuai dengan fungsi cuka kayu sebagai pemercepat pertumbuhan, inhibitor dan pupuk organik alam menurut Yatagai (2002) dan Anonim (2002). Pemanfaatan cuka kayu distilat 2,5\% dari serbuk gergaji kayu campuran dengan 4 kali penyemprotan pada tanaman padi seluas $2500 \mathrm{~m}^{2}$ diperlukan 9 liter cuka kayu distilat atau $36 \mathrm{l} / \mathrm{ha}$. Dengan mengetahui rendemen cuka kayu distilat dari 'crude' cuka kayu 95\% dan sifat cuka kayu yang sama antara sgha dan sght, maka penggunaan cuka kayu distilat pada budidaya tanaman padi berasal dari bahan baku serbuk gergaji kayu campuran asal hutan tanaman sebanyak 71,5 kg pada kadar air 30,5\% yang diproduksi terpadu dengan arangnya pada tungku blower (Tabel 1). 
Tabel 8. Produksi arang aktif dari arang serbuk gergaji hutan tanaman Table 8. Activated charcoal production of sawdust charcoal of forest plantation

\begin{tabular}{|l|c|c|}
\hline \multicolumn{1}{|c|}{ Parameter } & $\begin{array}{c}\text { Aktifasi asam fosfat 20\% dan uap } \\
\text { air (Phosphate acid and steam } \\
\text { activation) }\end{array}$ & $\begin{array}{c}\text { Aktifasi dengan uap air } \\
\text { (Steam activation) }\end{array}$ \\
\hline $\begin{array}{l}\text { Berat arang (Weight of } \\
\text { charcoa), } \mathrm{kg}\end{array}$ & 11,5 & 10,8 \\
\hline $\begin{array}{l}\text { Uap air (Steam), liter/jam } \\
\text { (hour) }\end{array}$ & 2 & 2 \\
\hline $\begin{array}{l}\text { Suhu aktifasi (Activation } \\
\text { temperature), }{ }^{\circ} \mathrm{C}\end{array}$ & 695 & 605 \\
\hline $\begin{array}{l}\text { Lama aktifasi (Activation } \\
\text { duration), jam (hour) }\end{array}$ & 3 & 36 \\
\hline Kayu bakar (Fuel wood), $\mathrm{kg}$ & 95 & 5,2 \\
\hline $\begin{array}{l}\text { Berat arang aktif }(\text { Weight of } \\
\text { activated charcoa), } \mathrm{kg}\end{array}$ & 5,7 & \\
\hline
\end{tabular}

Tabel 9. Sifat arang aktif dari arang serbuk gergaji hutan tanaman Table 9. Activated charcoal of sawdust charcoal of forest plantation

\begin{tabular}{|l|c|c|}
\hline \multicolumn{1}{|c|}{ Parameter } & $\begin{array}{c}\text { Aktifasi dengan asam fosfat } \\
20 \% \text { dan uap air (Phosphate acid } \\
\text { and steam activation) }\end{array}$ & $\begin{array}{c}\text { Aktifasi dengan ap air } \\
\text { (Steam activation) }\end{array}$ \\
\hline $\begin{array}{l}\text { Rendemen dari contoh arang } \\
\text { (Yield of charcoal material), \% }\end{array}$ & 49,6 & 48,1 \\
\hline $\begin{array}{l}\text { Rendemen dari contoh serbuk } \\
\text { gergaji (Yield of sawdust material), } \\
\%\end{array}$ & 8,2 & 8,0 \\
\hline Kadar air (Moisture content), \% & 6,5 & 6,5 \\
\hline Kadar abu (Ash content), \% & 16,4 & 8,5 \\
\hline $\begin{array}{l}\text { Kadar zat terbang (Volatile } \\
\text { matter content), \% }\end{array}$ & 8,2 & 80,7 \\
\hline $\begin{array}{l}\text { Kadar karbon tertambat (Fixed } \\
\text { carbon content), \% }\end{array}$ & 75,5 & 798,7 \\
\hline $\begin{array}{l}\text { Daya serap iod (Iod absorption), } \\
\text { mg/g }\end{array}$ & 857,7 & 11,0 \\
\hline $\begin{array}{l}\text { Daya serap benzene (Benzena } \\
\text { absorption), \% }\end{array}$ & 9,4 & \\
\hline
\end{tabular}


Tabel 10. Penggunaan cuka kayu distilasi pada tanaman padi Table 10. Utilization of distillated wood vinegar on padi plantation

\begin{tabular}{|c|c|c|c|c|}
\hline $\begin{array}{l}\text { Perlakuan } \\
\text { (Treatment) }\end{array}$ & \multirow[t]{2}{*}{$\begin{array}{l}\text { Tinggi tanaman } \\
(\text { High of plantation), }\end{array}$} & \multirow[t]{2}{*}{$\begin{array}{c}\text { Jumlah gabah per } \\
\text { malai (Total of } \\
\text { unhulled rice } \\
\text { per spire) }\end{array}$} & \multirow{2}{*}{$\begin{array}{l}\text { Bobot } 1000 \\
\text { butir } \\
\text { (Weight of } \\
1000 \text { grain), } \\
\text { g }\end{array}$} & \multirow[t]{2}{*}{$\begin{array}{l}\text { Gabah kering } \\
\text { giling (Unhulled } \\
\text { rice of dry } \\
\text { grinder), ton/ha }\end{array}$} \\
\hline $\begin{array}{l}\text { Dengan pupuk } \\
\text { NPK (With NPK } \\
\text { fertilizer) }\end{array}$ & & & & \\
\hline $\begin{array}{l}\text { Cuka kayu serbuk } \\
\text { gergaji dari } \\
\text { tungku blower } \\
\text { (Sawdust wood } \\
\text { vinegar of blow } \\
\text { kiln), 2,5\% }\end{array}$ & 62,1 & 107,08 & 25,59 & 5,77 \\
\hline $\begin{array}{l}\text { Bahan organik } \\
\text { (Organic materia), } \\
2,5 \%\end{array}$ & 59,8 & 103,38 & 25,37 & 5,78 \\
\hline Kontrol (Contro) & 57,4 & 101,17 & 25,90 & 5,36 \\
\hline $\begin{array}{l}\text { Tanpa pupuk } \\
\text { NPK (Without } \\
\text { NPK fertilizer) }\end{array}$ & & & & \\
\hline $\begin{array}{l}\text { Cuka kayu } \\
\text { serbuk gergaji } \\
\text { dari tungku } \\
\text { blower (Sawdust } \\
\text { wood vinegar of } \\
\text { blow kiln), 2,5\% }\end{array}$ & $\begin{array}{l}\text { (Sawdust wood } \\
\text { vinegar of blow } \\
\text { kiln), 2,5\% }\end{array}$ & 103,71 & 26,91 & 4,41 \\
\hline $\begin{array}{l}\text { Bahan organik } \\
\text { (Organic material), } \\
2,5 \%\end{array}$ & 58,5 & 102,92 & 26,76 & 4,10 \\
\hline Kontrol (Control) & 56 & 102,75 & 27,10 & 3,21 \\
\hline
\end{tabular}

\section{KESIMPULAN DAN SARAN}

\section{A. Kesimpulan}

1. Laju pembakaran sgha rata-rata $4,091 \mathrm{~kg} / \mathrm{jam}$ menunjukan angka lebih rendah dari laju pembakaran sght rata-rata 4,943 kg/jam dan laju produksi terpadu arang dan cuka kayu 'crude'dari sgha dan sght pada tungku sakuraba masing-masing 0,999 kg/jam dan 0,912 $\mathrm{kg} / \mathrm{jam}$ dan pada tungku blower 1,644 kg/jam dan 1,925 kg/jam. Produksi terpadu dari sgha dan sght pada tungku sakuraba masing-masing 292,68 kg/ton dan 232,24 kg/ton dan pada tungku blower $344,76 \mathrm{~kg} /$ ton dan $323,07 \mathrm{~kg} /$ ton. Produksi terpadu pada tungku blower lebih baik dari tungku sakuraba. 
2. Rendemen arang sgha adalah sama dengan sght (19,8\%) dihitung dari berat kering dan sifatnya berbeda pada penggunaan tungku. Sifat arang dari tungku blower lebih baik dari tungku sakuraba dan ini ditunjukan oleh kadar abu $(2,2 \%)$ dan kadar zar mudah terbang $(11,9 \%)$ yang lebih rendah, dan kadar karbon tertambat (86,7\%) yang lebih tinggi.

3. Rendemen dan sifat cuka kayu 'crude' sgha dan sght tidak menunjukan perbedaan, tetapi berbeda sifatnya pada pemakaian tungku. Rendemen cuka kayu 'crude' pada tungku blower $(22 \%)$ lebih tinggi dari tungku sakuraba $(14,6 \%)$ dihitung dari berat kering. Cuka kayu hasil distilasi memenuhi mutu cuka kayu Jepang untuk semua parameter sedang cuka kayu 'crude' tidak memenuhi pada warna dan transparansi.

4. Cuka kayu 'crude' sgha dan sght mengandung jenis komponen kimia yang sama pada kadar yang bervariasi, terdiri dari kadar asam asetat antara 7,121 - 9,971 ppm, metanol 2,086 - 3,543 ppm, fenol 1,495 - 2,200 ppm, asetol 0,309 -0,828 ppm, orto kreosol 2,3912,598 ppm, para kreosol 1,110 - 2,183 ppm, furfural 1,393-2,054 ppm, alfa metilguaiakol 1,697-2,300 ppm, sikloheksana 1,039-1,443 ppm.

5. Produksi arang aktif dari arang sgha dan sght pada aktifasi dengan perendaman asam fosfat $5 \%$ dan uap air menghasilkan kualitas arang aktif yang tidak memenuhi syarat Standar Nasional Indonesia karena daya serap iod yang rendah yaitu pada kisaran 454 - 556 $\mathrm{mg} / \mathrm{g}(>750 \mathrm{mg} / \mathrm{g})$. Daya serap iod dapat ditingkatkan dari 469,9 mg/g menjadi 857,7 $\mathrm{mg} / \mathrm{g}$ dan $789,7 \mathrm{mg} / \mathrm{g}$ masing-masing dihasilkan dari aktifasi sght dengan asam fosfat $20 \%$ dan uap air pada suhu $695^{\circ} \mathrm{C}$ dan uap air tanpa asam fosfat pada suhu $605^{\circ} \mathrm{C}$. Peningkatan kualitas arang aktif yang memenuhi SNI ini diperoleh setelah tungku aktifasi diredam emisi panasnya dengan woolglass.

6. Pemanfaatan cuka kayu distilasi 2,5\% pada tanaman padi jenis ciherang dengan perlakuan penambahan pupuk NPK dapat menggantikan penggunaan bahan organik 2,5\% dengan hasil gabah kering giling yang sama yaitu 5,75 ton/ha. Perlakuan tanpa pupuk NPK menghasilkan gabah kering giling paling tinggi pada cuka kayu 4,41 ton/ha, bahan organik 4,10 ton / ha dan paling rendah pada kontrol 3,21 ton/ha. Selisih gabah kering giling cuka kayu dengan bahan organik dan kontrol 0,31 ton/ha dan 0,89 ton/ha memberi petunjuk bahwa cuka kayu distilat 2,5\% mengandung komponen pupuk dan memberi respon lebih baik pada pertumbahan padi.

7. Penggunan cuka kayu distilat $2,5 \%$ pada budidaya tanaman padi dengan cara penyemprotan sebanyak 8 kali adalah 9 liter. Jumlah cuka kayu distilat ini berasal dari serbuk gergaji hutan tanaman $71,5 \mathrm{~kg}$ pada kadar air 30,5\% yang diproses menjadi cuka kayu 'crude' terpadu dengan arang pada tungku blower dan rendemen cuka kayu distilat $95 \%$.

\section{B. Saran}

Produksi cuka kayu dari serbuk gergaji kayu campuran yang dipadukan dengan produksi arangnya dalam satu unit peralatan tungku blower perlu diteliti sifat dan karakteristik cuka kayu sebagai pupuk organik cair. 


\section{DAFTAR PUSTAKA}

Anonim. 1980. Pembuatan arang serbuk gergaji kayu campuran pada tungku Mark V. Laboratorium Kelti Kimia dan Energi Biomassa Hasil Hutan. Pusat Penelitian dan Pengembangan Hasil Hutan. Bogor.

. 1959. Standar method of coal and coke ASTM D-5. American Society for Testing Materials. Philadelphia.

.1995. Arang aktif teknis. SNI 06-3730-1995. Badan Standardisasi Nasional, Jakarta.

.2000. Teknologi alternatif pemanfaatan limbah. Kelti Pengolahan Kimia dan Energi Hasil Hutan. Makalah Utama Lokakarya Penelitian Hasil Hutan tgl. 7 Desember 2000. Bogor.

.2002. Wood vinegar. Forest Energy Forum No. 9. FAO.

Djeni Hendra. 2006. Pembuatan arang aktif dari tempurung kelapa sawit dan serbuk gergaji kayu campuran. Jurnal Penelitian Hasil Hutan 24(2):134. Bogor.

Martawijaya, A. dan P. Sutigno. 1990. Peningkatan efisiensi dan produktivitas pengolahan kayu melalui pengurangan dan pemanfaatan limbah. Seminar Teknologi Perkayuan. Jakarta, 22 Januari 1990.

Gusmailina, Gustan Pari dan Sri Komarayati. 2002. Pedoman pembuatan arang kompos. Pusat Penelitian dan Pengembangan Teknologi Hasil Hutan. Bogor.

Tjutju Nurhayati. 1984. Karbonisasi beberapa jenis kayu perdagangan. Makalah Penunjang pada Ceramah dan Diskusi Pekan Ekspor Arang di Pekanbaru tgl. 30 -31 Oktober 1984. Kantor Wilayah Perdagangan dan Ekspor Propinsi Riau

2002. Prospek pengembangan komoditas wood vinegar. Prosiding Pertemuan dan Presentasi Ilmiah Standardisasi dan Jaminan Mutu Jakarta, 2 - 3 Oktober. Badan Standardisasi Nasional. Jakarta.

Yatagai Mitsuyoshi. 2002. Utilization of charcoal and wood vinegar in Japan. Graduate School of Agricultural and Life Sciences, The University of Tokyo. 